\title{
Spinal brucellosis: a forgotten cause of chronic back pain
}

\author{
Sawsan Taif, ${ }^{1}$ Asif Alrawi ${ }^{2}$
}

${ }^{1}$ Department of Radiology, Khoula Hospital, Muscat, Oman

${ }^{2}$ Department of Orthopedics, Khoula Hospital, Muscat, Oman

\section{Correspondence to}

Dr Sawsan Taif, sawsantaif@gmail.com

Accepted 6 June 2014
CrossMark

To cite: Taif S, Alrawi A BMJ Case Rep Published online: [please include Day Month Year] doi:10.1136/ bcr-2014-205816

\section{DESCRIPTION}

A 67-year-old woman presented to the orthopaedic department with chronic back pain gradually progressing over the last few years. In the past 2 months the pain became very severe and prevented her from walking. She had no fever, radiculopathy or bladder dysfunction. Physical examination showed mild tenderness and restriction of movement with no neurological deficit.

Initial laboratory tests revealed white cell count of 13000 with $78 \%$ neutrophils, erythrocyte sedimentation rate $89 \mathrm{~mm} / \mathrm{h}$ and $\mathrm{C}$ reactive protein $66 \mathrm{mg} / \mathrm{L}$. Lumbar spine radiograph showed degenerative changes; however, multiple erosions and sclerosis were noted in the vertebral endplates around the narrowed disc spaces (figure 1A). In light of these imaging findings, an infective process was suspected. Consequently, MRI was requested which revealed extensive bone marrow oedema at multiple levels, endplate erosions and reduced disc heights without gross fluid collections (figure $1 \mathrm{~B}, \mathrm{C}$ ). Imaging findings were in keeping with spondylodiscitis with the differential diagnosis included pyogenic and tuberculous pathologies. Although less common, brucellosis was another possibility due to the patient being from an endemic area. Subsequently, blood culture revealed growth of brucella species and serology tests revealed a high antibody titre to brucella which confirmed the diagnosis.

Posterior spinal stabilisation with surgical debridement was carried out (figure 2). Tissue biopsy revealed non-specific inflammation and tuberculous culture was negative. Antimicrobial treatment included streptomycin for 2 weeks and rifampicin and doxycycline for 2 months. The patient underwent regular follow-up and had excellent improvement of symptoms.

Brucellosis is a systemic disease endemic in Middle Eastern and Mediterranean areas. Spinal involvement is common and mimics osteoarthritis due to reactive sclerosis, osteophytosis and lack of
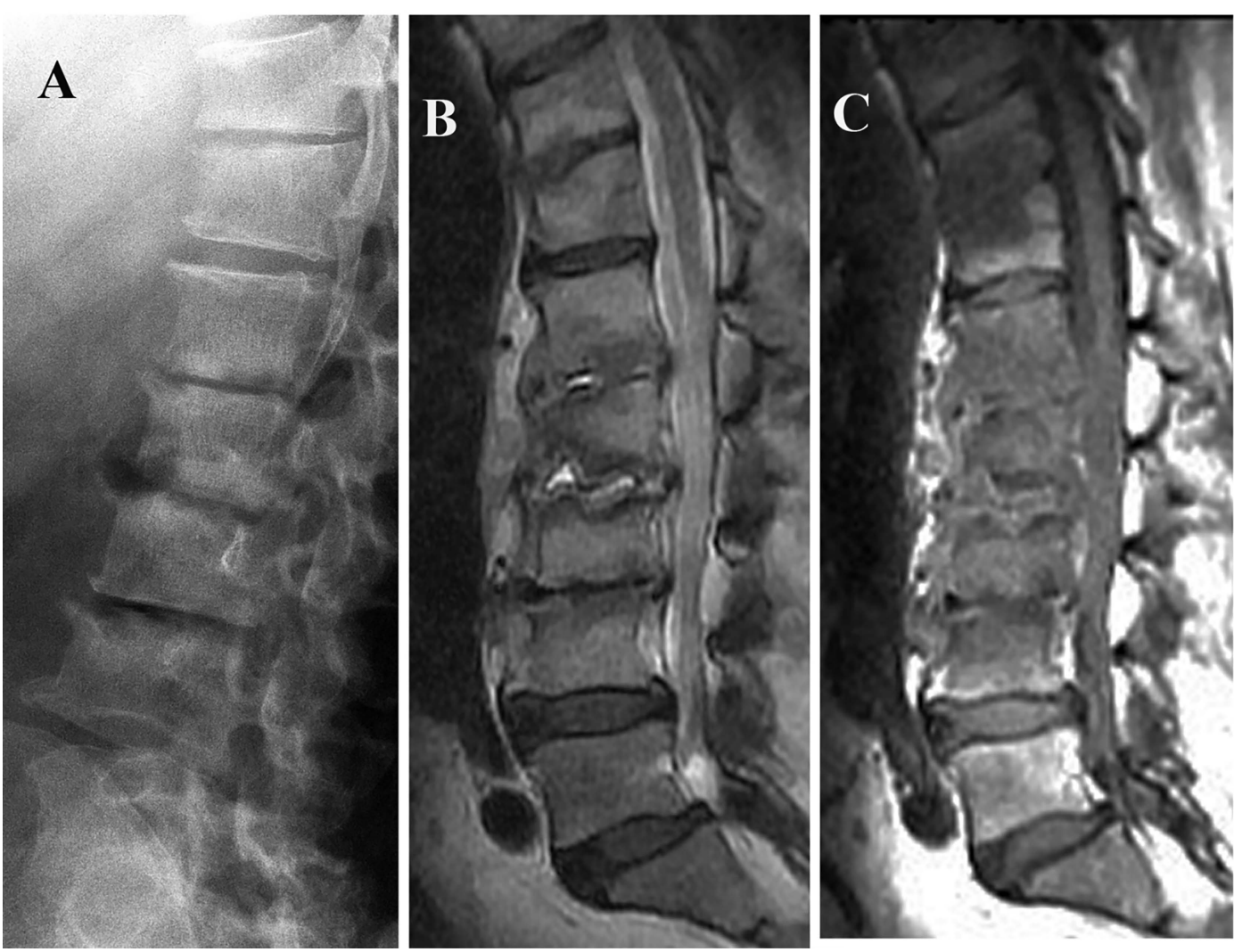

Figure 1 Spondylodiscitis: (A) lateral lumbar spine radiograph showing multilevel disc spaces narrowing, endplate erosions, sclerosis and osteophytes. Sagittal MRI, T2-weighted (B) and T1-weighted (C) images reveal bone marrow oedema (low signal on T1 image), reduced disc heights with endplate erosions at D11-12, L1-2, L2-3 and L3-4. A small amount of fluid is seen in L1-2 and L2-3 discs. 


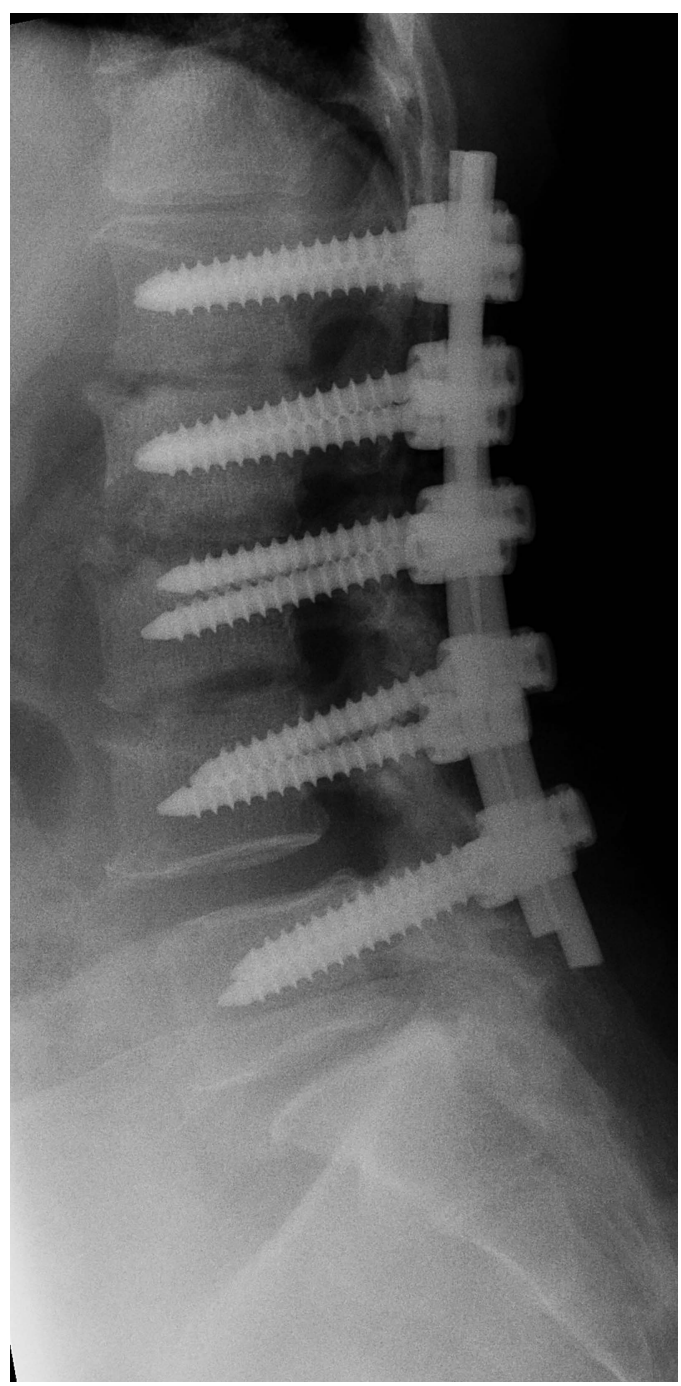

considerable bone destruction. A high index of suspicion is necessary to make the diagnosis, therefore laboratory tests for brucellosis are recommended in back pain with atypical presentation; and particularly if imaging studies revealed vertebral endplate erosions, sclerosis and little fluid, particularly in the presence of multilevel involvement. ${ }^{12}$

\section{Learning points}

- Spinal brucellosis is occasionally slowly progressive so that patients present with chronic backache.

- Spinal brucellosis can mimic degenerative changes and other types of infection such as tuberculosis which require entirely different forms of treatment; therefore in endemic areas a high index of suspicion is necessary to make the diagnosis.

- Brucellosis has to be considered if imaging studies reveal sclerosis and osteophytosis with little fluid collection, which may differentiate it from other types of infection.

Contributors ST and AA were involved in data collection, interpretation and writing of the manuscript.

Competing interests None.

Patient consent Obtained.

Provenance and peer review Not commissioned; externally peer reviewed.

\section{REFERENCES}

1 Al-Shahed MS, Sharif HS, Haddad MC, et al. Imaging features of musculoskeletal brucellosis. Radiographics 1994;14:333-48.

2 Pourbagher A, Pourbagher MA, Savas L, et al. Epidemiologic, clinical, and imaging findings in brucellosis patients with osteoarticular involvement. AJR Am J Roentgenol 2006; 187:873-80.

Figure 2 Postoperative lumbar spine radiograph showing posterior stabilisation from L1 to L5.

Copyright 2014 BMJ Publishing Group. All rights reserved. For permission to reuse any of this content visit http://group.bmj.com/group/rights-licensing/permissions.

BMJ Case Report Fellows may re-use this article for personal use and teaching without any further permission.

Become a Fellow of BMJ Case Reports today and you can:

- Submit as many cases as you like

- Enjoy fast sympathetic peer review and rapid publication of accepted articles

- Access all the published articles

- Re-use any of the published material for personal use and teaching without further permission

For information on Institutional Fellowships contact consortiasales@bmjgroup.com

Visit casereports.bmj.com for more articles like this and to become a Fellow 